\title{
The Effect of Neem Seed Oil (Azadirachta indica) and Clove Leaf Oil (Syzygium aromaticum) Mixture on Cabbage Head Caterpillars (Crocidolomia pavonana)
}

\author{
Utami Dwi Ginasti ${ }^{1}$, Danar Dono ${ }^{2 *}$, Toto Sunarto ${ }^{2}$ \\ ${ }^{1}$ Alumny of Agrotechnology study program, Agriculture Faculty, Universitas Padjadjaran, Jatinangor, West Java, 45363. \\ ${ }^{2}$ Departemen of Plan Pest and Diseases, Agriculture Faculty, Universitas Padjadjaran, Jatinangor, West Java, 45363. \\ *Corresponding Author: danar.dono@unpad.ac.id
}

Received October 13, 2020; revised November 04, 2020; accepted November 10, 2020

\begin{abstract}
Crocidolomia pavonana is one of the important pest in Brassicaceae family. The used of botanical pesticides such as neem and clove can be used as alternative control for C. pavonana. This study aimed to examine the effect of neem oil, clove oil, and its mixture to C. pavonana. This experiment was conducted from November 2019 to May 2020 at the Laboratory Pesticides and Environmental Toxicology of the Department of Plant Pests and Diseases of the Faculty of Agriculture, Universitas Padjadjaran. The experimental method used in this research was Randomized Block Design with 21 treatments, i.e control, neem oil, clove oil, and its mixture at concentrations of $0,1 \%, 0,25 \%, 0,5 \%$, and $1 \%$, each treatments was replicated 3 times. The result of this experiment showed that single or mixed treatments (Neem : Clove) at consentration of $1 \%$ caused $100 \%$ larvae mortality. Mixed treatment at ratio 1:1 could inhibits the formation of pupa and imago, and could prolong the development time of larvae in instar II-III and instar II-IV. In addition, mixed treatment at ratio 2:1 was also prolong the development time of larvae in instar II-pupa, reduce food consumption, inhibit the formation of imago, and reduce the number of eggs C. pavonana.
\end{abstract}

Keywords: Brassicaceae, Combination insecticides, Botanical pesticides, Toxicity

ABSTRAK

Pengaruh Campuran Minyak Biji Mimba (Azadirachta indica) dan Minyak Daun Cengkeh (Syzygium aromaticum) terhadap Ulat Krop Kubis (Crocidolomia pavonana)

Crocidolomia pavonana merupakan hama penting pada tanaman Brassicaceae. Penggunaan pestisida nabati seperti mimba dan cengkeh dapat digunakan sebagai alternatif pengendalian C. pavonana. Penelitian ini bertujuan untuk menguji pengaruh minyak mimba dan cengkeh serta campurannya terhadap C. pavonana. Percobaan dilaksanakan pada bulan November 2019 hingga Mei 2020 di Laboratorium Pestisida dan Toksikologi Lingkungan Departemen Hama dan Penyakit Tumbuhan Fakultas Pertanian Universitas Padjadjaran. Metode yang digunakan yaitu metode eksperimen dengan Rancangan Acak Kelompok yang terdiri dari 21 perlakuan yaitu kontrol, minyak mimba, minyak cengkeh dan campurannya pada konsentrasi $0,1 \%, 0,25 \%, 0,5 \%$, dan $1 \%$, setiap perlakuan diulang sebanyak 3 kali. Hasil percobaan menunjukkan bahwa perlakuan tunggal maupun campuran (Mimba : Cengkeh) pada konsentrasi 1\% menyebabkan mortalitas larva 100\%. Perlakuan campuran dengan rasio 1:1 dapat menghambat terbentuknya pupa dan imago, serta dapat memperpanjang waktu perkembangan larva instar II-III dan instar II-IV. Perlakuan campuran dengan rasio 2:1 dapat memperpanjang waktu perkembangan larva instar II-pupa, menghambat munculnya imago, meurunkan konsumsi pakan, serta dapat menurunkan jumlah telur C. pavonana.

Kata Kunci: Brassicaceae, Kombinasi insektisida, Pestisida nabati, Toksisitas

\section{PENDAHULUAN}

Petani biasanya menggunakan pestisida sintetik dalam mengendalikan C. pavonana di pertanaman. Penggunaan pestisida sintetik yang sulit terdegradasi dan terus menerus dapat menimbulkan dampak negatif seperti menurunkan keanekaragaman hayati, menurunkan populasi organisme berguna seperti lebah dan musuh alami, serta residunya dapat mencemari lingkungan (Isenring, 2010). Oleh karena itu untuk pengendalian $C$. pavonana perlu dicari pengendalian alternatif yang lebih ramah lingkungan, misalnya menggunakan insektisida nabati. Insektisida nabati telah lama dikenal sebagai alternatif pengendalian hama pengganti insektisida sintetik karena hanya memiliki sedikit ancaman terhadap lingkungan dan kesehatan manusia (Wakeil, 2013).
Indonesia memiliki keanekeragaman hayati yang cukup besar termasuk berbagai tumbuhan yang dapat digunakan sebagai insektisida nabati seperti mimba dan cengkeh.

Minyak mimba memiliki senyawa aktif utama yaitu azadirakhtin dan senyawa hasil metabolit sekunder lainnya yaitu meliantriol, nimbin, nimbidin, serta salanin. Formulasi minyak biji mimba dapat bekerja sebagai repellent, antifeedant, ovisidal, larvasida, dan penghambat pertumbuhan terhadap serangga hama (Chaudhary et al., 2017). Hasil penelitian Dono et al. (2020) menunjukkan bahwa minyak biji mimba memiliki nilai $\mathrm{LC}_{50}$ sebesar $0,08 \%$ terhadap Spodoptera frugiperda. Duarte et al. (2019) juga melaporkan bahwa minyak mimba memiliki nilai $\mathrm{LC}_{50}$ dan $\mathrm{LC}_{90}$ masing-masing sebesar $9.500 \mathrm{ppm}$ dan 
17.230 ppm terhadap larva $S$. frugiperda. Selain itu, Formulasi mimba dengan konsentrasi $1 \%$ dapat menyebabkan mortalitas larva C. pavonana $100 \%$ pada 72 jam setelah aplikasi, dan juga dapat menekan penetasan telur C. pavonana (Balfas \& Mardiningsih, 2016).

Selain minyak mimba, minyak cengkeh juga dapat digunakan sebagai pestisida nabati. Minyak cengkeh mengandung eugenol sebagai senyawa aktif utama dalam mengendalikan organisme pengganggu tanaman (OPT), selain itu daun cengkeh juga mengandung senyawa alkaloid, tannin, saponin, dan flavonoid (Talahatu \& Papilaya, 2015). Hasil penelitian Balfas (2008) menunjukkan bahwa, Minyak Daun Cengkeh (MDC) dapat mengakibatkan mortalitas Planococcus minor hampir $90 \%$ pada konsentrasi 5\%. Bhat \& Kempraj (2009) melaporkan bahwa minyak daun cengkeh memiliki nilai $\mathrm{LC}_{50}$ dan $\mathrm{LC}_{95}$ masing-masing sebesar $5,30 \mathrm{mg} / \mathrm{ml}$ dan 7,03 $\mathrm{mg} / \mathrm{ml}$ terhadap Aedes albopictus. Selain itu, minyak cengkeh konsentrasi $0,5 \%$ juga dapat menyebabkan mortalitas $C$. pavonana $34 \%$ pada 72 jam setelah aplikasi (Balfas \& Mardiningsih, 2016).

Pestisida nabati dapat digunakan secara tunggal ataupun dicampurkan dengan tumbuhan lainya untuk meningkatkan keefektifannya (Chaudhary et al., 2017). Pencampuran insektisida yang bersifat sinergis akan lebih efisien dibandingkan perlakuan tunggalnya karena pada insektisida campuran, dosis yang digunakan akan lebih rendah (Yuswanti \& Prijono, 2004). Campuran ekstrak daun Tephrosia vogelii bunga ungu dengan ekstrak buah Piper cubeba dengan perbandingan 5:9 bersifat sinergis terhadap larva $C$. pavonana (Abizar \& Prijono, 2010). Nailufar \& Prijono (2017) juga melaporkan bahwa campuran ekstrak buah Piper aduncum dan ekstrak daun $T$. vogelii menunjukkan pengaruh sinergisme yang kuat terhadap C. pavonana. Campuran minyak cengkeh dan ekstrak biji mimba sudah diketahui keefektifannya terhadap patogen Phakopsora pachyrhizi dengan perbandingan 1:1 dapat menekan intensitas penyakit karat pada tanaman kedelai berumur 7 MST menjadi 52\%, dibandingkan perlakuan kontrol yang intensitas penyakitnya mencapai 95,88\% (Sumartini, 2016). Penelitian ini bertujuan untuk menguji pengaruh minyak mimba dan cengkeh serta campurannya pada berbagai rasio perbandingan terhadap ulat krop kubis (C. pavonana).

\section{BAHAN DAN METODE}

Percobaan dilaksanakan di Laboratorium Pestisida dan Toksikologi Lingkungan, Departemen Hama dan Penyakit Tumbuhan, Fakultas Pertanian, Universitas Padjadjaran pada bulan November 2019 hingga Mei 2020. Minyak biji mimba diperoleh dari Puspromit (Pusat Studi Pengembangan Produk dan Kemitraan), Departemen Hama dan Penyakit Tumbuhan, Fakultas Pertanian, Universitas Padjadjaran, sedangkan minyak daun cengkeh diperoleh dari toko dan distributor bahan kimia.
Percobaan tersusun atas 21 perlakuan yaitu kontrol, minyak mimba, minyak cengkeh, dan campurannya pada rasio (Mimba : Cengkeh) 1:1, 1:2, dan 2:1. Setiap perlakuan minyak nabati secara tunggal maupun campuran diuji pada konsentrasi $0,1 \%, 0,25 \%, 0,5 \%$, dan $1 \%$. Percobaan dilakukan dengan 3 kali pengulangan. Perlakuan dengan konsentrasi $1 \%$ dibuat dengan cara $1 \mathrm{ml}$ minyak nabati dimasukkan ke dalam labu ukur kemudian ditambahkan larutan pengemulsi hingga volumenya $100 \mathrm{ml}$. larutan pengemulsi terdiri dari akuades yang mengandung $2 \%$ campuran pengemulsi (Tween 80 dan Span 80) dengan perbandingan 4:1. Begitu juga pada perlakuan lainnya, minyak dari biji mimba dan minyak daun cengkeh diambil sesuai rasio dan konsentrasi yang diperlukan, kemudian ditambah larutan pengemulsi hingga volumenya mencapai 100 $\mathrm{ml}$.

Uji hayati dilakukan dengan metode celup daun pakan (Prijono, 1999) yaitu dengan cara daun brokoli segar dipotong cakram diameter $3 \mathrm{~cm}$. Daun yang telah dipotong lalu dicelupkan satu per satu dalam larutan minyak nabati selama 10 detik kemudian dikering-anginkan. Daun kontrol dicelupkan dalam air pengencer (air+pengemulsi) tanpa campuran minyak nabati. Daun yang telah dicelupkan diletakkan dalam wadah plastik yang telah dialasi kertas hisap. Pada setiap perlakuan digunakan dua potong daun berperlakuan, kemudian serangga uji $C$. pavonana dimasukkan ke dalam wadah plastik sebanyak 10 ekor larva instar II. Larva diberi daun berperlakuan selama 48 jam. Setelah 48 jam masa perlakuan, daun pakan diganti dengan daun tanpa perlakuan. Larva perlakuan dan kontrol dipelihara serta diamati hingga berkembang mencapai imago.

\section{Mortalitas Larva $C$. pavonana}

Pengamatan mortalitas dilakukan setiap hari hingga larva mencapai instar IV. Mortalitas larva $C$. pavonana dihitung dengan rumus:

$$
\text { Mortalitas (\%) }=\frac{\text { jumlah C.pavonana yang mati }}{\text { jumlah C.pavonana yang diuji }} \times 100 \%
$$

\section{Waktu Perkembangan Larva $C$. pavonana}

Waktu perkembangan $C$. pavonana diamati setiap hari dengan menghitung lama waktu yang dibutuhkan larva dalam proses pergantian instar hingga menjadi pupa.

\section{Konsumsi Pakan Larva $C$. pavonana}

Pengamatan konsumsi pakan dilakukan pada 48 jam setelah perlakuan. Pertama-tama dilakukan perhitungan kadar biomassa dari hasil pengujian ratarata bobot sampel daun sebagai faktor koreksi. Bobot basah awal daun diperoleh dengan menimbang daun sampel. Daun kemudian dikeringkan menggunakan oven selama 24 jam dengan suhu $90^{\circ} \mathrm{C}$. Bobot kering dari daun sampel yang telah dioven dimasukkan 
dalam rumus berikut untuk mengitung kadar biomassa.

$$
\mathrm{KB}=\frac{\mathrm{BK}}{\mathrm{BB}} \times 100 \%
$$

Keterangan:

$\mathrm{BK}=$ Bobot kering sampel

$\mathrm{BB}=$ Bobot basah sampel

$\mathrm{KB}=\%$ Kadar Biomassa

Bobot basah pakan yang akan diuji ditimbang terlebih dahulu sebelum diberi perlakuan sehingga dapat diperoleh bobot kering awal dengan rumus:

$$
\mathrm{BKa}=\mathrm{BBa} \times \mathrm{KB}
$$

Keterangan:

$\mathrm{BBa}=$ Bobot basah awal

$\mathrm{BKa}=$ Bobot kering awal

Sisa daun yang telah dikonsumsi kemudian dioven selama 48 jam pada suhu $90^{\circ} \mathrm{C}$, kemudian ditimbang untuk mengetahui bobot kering akhir (BK). Bobot konsumsi pakan dihitung dengan rumus:

$$
\text { Bobot konsumsi pakan }=\frac{\mathrm{BKa}-\mathrm{BK}}{\mathrm{BKa}} \times 100 \%
$$

\section{Berat Larva dan Pupa $C$. pavonana}

Bobot larva ditimbang pada larva instar IV yang masih bertahan hidup. Bobot pupa ditimbang pada hari ke 3 setelah pupa berhasil terbentuk.

\section{Keberhasilan Larva $C$. pavonana Menjadi Pupa dan Imago}

Pengamatan dilakukan pada setiap perlakuan dengan cara menghitung jumlah pupa dan imago yang berhasil terbentuk.

\section{Reproduksi Imago C. pavonana}

Imago yang muncul dipisahkan ke dalam wadah plastik sebanyak satu pasang setiap wadah. Daun brokoli dimasukkan ke dalam wadah sebagai tempat peletakkan telur. Panen telur dilakukan setiap hari hingga imago tidak memproduksi telur lagi. Telur yang telah dipanen dihitung jumlahnya setiap hari.

\section{HASIL DAN PEMBAHASAN}

\section{Mortalitas Larva $C$. pavonana}

Hasil percobaan menunjukkan bahwa semua perlakuan tunggal maupun campuran antara minyak mimba dan minyak cengkeh pada konsentrasi $1 \%$ dapat mencapai mortalitas larva C. pavonana sebesar $100 \%$. Perlakuan campuran dengan rasio $1: 1 \quad 0,5 \%$ menghasilkan mortalitas larva $93.33 \%$, lebih tinggi dibandingkan perlakuan lainnya pada konsentrasi yang sama (Gambar 1), tetapi tidak berbeda nyata dengan perlakuan lainnya pada konsentrasi yang sama menurut hasil uji Gugus Scott-Knott pada taraf nyata

\begin{tabular}{|c|c|}
\hline Perlakuan & Mortalitas larva $( \pm \mathrm{SB})(\%)$ \\
\hline Kontrol & $6,67 \pm 5,77$ a \\
\hline Mimba tunggal $0,1 \%$ & $70,00 \pm 30,00 \mathrm{c}$ \\
\hline Mimba tunggal 0,25\% & $80,00 \pm 17,32 \mathrm{c}$ \\
\hline Mimba tunggal $0,5 \%$ & $80,00 \pm 34,64 \mathrm{c}$ \\
\hline Mimba tunggal $1 \%$ & $100,00 \pm 0,00 \mathrm{c}$ \\
\hline Cengkeh tunggal $0,1 \%$ & $33,33 \pm 20,82 b$ \\
\hline Cengkeh tunggal $0,25 \%$ & $36,67 \pm 25,17 b$ \\
\hline Cengkeh tunggal $0,5 \%$ & $76,67 \pm 40,42 \mathrm{c}$ \\
\hline Cengkeh tunggal $1 \%$ & $100,00 \pm 0,00 \mathrm{c}$ \\
\hline 1:1 (Mimba : Cengkeh) $0,1 \%$ & $20,00 \pm 26,46 \mathrm{a}$ \\
\hline 1:1 (Mimba : Cengkeh) $0,25 \%$ & $56,67 \pm 23,09 \mathrm{~b}$ \\
\hline 1:1 (Mimba : Cengkeh) $0,5 \%$ & $93,33 \pm 5,77 \mathrm{c}$ \\
\hline 1:1 (Mimba : Cengkeh) $1 \%$ & $100,00 \pm 0,00 \mathrm{c}$ \\
\hline 1:2 (Mimba : Cengkeh) $0,1 \%$ & $16,67 \pm 5,77 \mathrm{a}$ \\
\hline 1:2 (Mimba : Cengkeh) $0,25 \%$ & $50,00 \pm 26,46 b$ \\
\hline 1:2 (Mimba : Cengkeh) $0,5 \%$ & $80,00 \pm 26,46 \mathrm{c}$ \\
\hline 1: 2 (Mimba : Cengkeh) $1 \%$ & $100,00 \pm 0,00 \mathrm{c}$ \\
\hline 2:1 (Mimba : Cengkeh) $0,1 \%$ & $26,67 \pm 15,28 \mathrm{a}$ \\
\hline 2:1 (Mimba : Cengkeh) 0,25\% & $63,33 \pm 32,15 c$ \\
\hline 2:1 (Mimba : Cengkeh) 0,5\% & $90,00 \pm 0,00 \mathrm{c}$ \\
\hline 2:1 (Mimba : Cengkeh) $1 \%$ & $100,00 \pm 0,00 \mathrm{c}$ \\
\hline
\end{tabular}
$5 \%$ (Tabel 1).

Tabel 1. Pengaruh minyak nabati terhadap mortalitas larva C. pavonana pada 11 HSP

Keterangan: Angka pada kolom yang sama yang diikuti dengan huruf yang sama tidak berbeda nyata menurut uji ScottKnott pada taraf nyata 5\%

$x$ : Rata-rata mortalitas larva C. pavonana $(\%)$

SB:Simpangan Baku 
Kematian larva mulai terjadi pada 1 hari setelah perlakuan (HSP) dan secara umum mulai meningkat tajam pada 2 HSP. Mortalitas $C$. pavonana cenderung stabil pada 6 HSP dan tidak terjadi penambahan kematian larva yang cukup berarti (Gambar 1).

Pada perlakuan cengkeh tunggal $1 \%$, mortalitasnya mencapai $100 \%$ pada hari pertama setelah diberi perlakuan, sedangkan pada perlakuan lainnya mortalitas larva mencapai $100 \%$ pada hari ke 1 - 5 setelah diberi perlakuan (Gambar 1). Pada perlakuan cengkeh tunggal $1 \%$, mortalitasnya mencapai $100 \%$ pada hari pertama setelah diberi perlakuan, sedangkan pada perlakuan lainnya mortalitas larva mencapai $100 \%$ pada hari ke $1-5$ setelah diberi perlakuan (Gambar 1). Hal tersebut sejalan dengan pernyataan Dewi et al. (2017) yang menyatakan bahwa senyawa aktif dalam minyak mimba tidak membunuh serangga uji secara cepat, biasanya memerlukan waktu $4-5$ hari untuk mati. Kematian larva pada perlakuan cengkeh tunggal $1 \%$ lebih cepat dibandingkan perlakuan mimba tunggal dan campuran karena minyak cengkeh memiliki senyawa aktif yang bekerja sebagai neurocontact. Pestisida yang bahan aktifnya bekerja terhadap sistem saraf serangga umumnya akan bereaksi lebih cepat (Hudayya \& Jayanti, 2012). Mimba memiliki senyawa aktif azadirakhtin yang bersifat sebagai penghambat pergantian kulit dengan cara merusak sistem hormon dan komunikasi kimiawi dalam proses pergantian kulit, selain itu kematian larva juga dapat disebabkan karena azadirakhtin dan senyawa dari minyak mimba lainnya seperti salanin berperan sebagai penghambat makan (antifeedant) sehingga serangga uji kelaparan dan kemudian mati (Dewi et al., 2017).


Gambar 1. Mortalitas kumulatif $C$. pavonana pada berbagai perlakuan. (a) $0,1 \%$, (b) $0,25 \%$, (c) $0,5 \%$, dan (d) $1 \%$

Lama Waktu Perkembangan Larva $C$. pavonana

Perlakuan campuran 1:1 (Mimba : Cengkeh)

$0,25 \%$ menghasilkan lama waktu perkembangan instar II-III dan instar II-IV yang lebih lama dibandingkan perlakuan lainnya yaitu masing masing 2,56 hari dan 5,44 hari, sedangkan pada perlakuan kontrol hanya membutuhkan waktu 1,22 hari dan 3,93 hari. Perlakuan 2:1 (Mimba : Cengkeh) 0,5\% juga menghasilkan waktu perkembangan larva instar IIpupa yang paling panjang yaitu 8,67 hari, sedangkan perlakuan kontrol hanya memerlukan waktu 6,66 hari (Tabel 2). Berdasarkan data tersebut dapat dibuktikan bahwa perlakuan campuran dapat meningkatkan keefektifan pestisida nabati dalam hal menghambat perkembangan larva dibandingkan perlakuan tunggalnya. 
Azadirakhtin dalam minyak mimba dapat menghambat pertumbuhan dan perkembangan larva karena dapat bekerja sebagai ecdysone blocker yaitu menghambat serangga untuk memproduksi dan melepas homon ekdison (Dewi et al., 2017). Hormon ekdison yaitu hormon yang berperan dalam mengontrol pembentukkan kutikula baru serangga dalam proses pergantian kulit. Selain itu salanin yang terkandung dalam minyak mimba juga dapat memperpanjang durasi tahap larva serta dapat menghambat pergantian kulit serangga (Chaudhary et al., 2017). Minyak cengkeh memiliki senyawa tannin yang dapat menghambat aktivitas enzim pencernaan dan aktivitas protein usus sehingga serangga akan memperoleh sedikit makanan dan kemudian menurunkan laju pertumbuhan serangga (Chintihia, 2015).

Tabel 2. Pengaruh minyak nabati terhadap lama waktu perkembangan larva $C$. pavonana

\begin{tabular}{|c|c|c|c|c|c|c|}
\hline \multirow{2}{*}{ Perlakuan } & \multicolumn{6}{|c|}{ Waktu Perkembangan $(\bar{x} \pm \mathrm{SB})$ (hari) } \\
\hline & Instar II-III & $\mathrm{N}$ & Instar II-IV & $\mathrm{n}$ & Instar II-pupa & $\mathrm{n}$ \\
\hline Kontrol & $1,22 \pm 0,23$ & 28 & $3,93 \pm 0,06$ & 28 & $6,66 \pm 0,52$ & 28 \\
\hline Mimba tunggal $0,1 \%$ & $1,71 \pm 1,58$ & 11 & $2,89 \pm 2,59$ & 9 & $5,78 \pm 5,00$ & 9 \\
\hline Mimba tunggal $0,25 \%$ & $2,14 \pm 1,91$ & 7 & $4,22 \pm 3,66$ & 6 & $6,11 \pm 5,30$ & 6 \\
\hline Mimba tunggal $0,5 \%$ & $0,90 \pm 1,57$ & 7 & $1,78 \pm 3,08$ & 6 & $2,72 \pm 4,72$ & 6 \\
\hline Mimba tunggal $1 \%$ & - & 0 & - & 0 & - & 0 \\
\hline Cengkeh tunggal $0,1 \%$ & $1,29 \pm 0,17$ & 26 & $3,97 \pm 0,27$ & 23 & $6,89 \pm 0,51$ & 20 \\
\hline Cengkeh tunggal $0,25 \%$ & $1,21 \pm 0,18$ & 25 & $4,08 \pm 0,18$ & 20 & $6,99 \pm 0,38$ & 19 \\
\hline Cengkeh tunggal $0,5 \%$ & $0,63 \pm 1,08$ & 8 & $1,05 \pm 1,81$ & 7 & $2,48 \pm 4,29$ & 7 \\
\hline Cengkeh tunggal $1 \%$ & - & 0 & - & 0 & - & 0 \\
\hline $1: 1(\mathrm{M}: \mathrm{C}) 0,1 \%$ & $2,03 \pm 0,25$ & 25 & $4,53 \pm 0,25$ & 24 & $7,35 \pm 0,88$ & 24 \\
\hline $1: 1(\mathrm{M}: \mathrm{C}) 0,25 \%$ & $2,56 \pm 1,39$ & 15 & $5,44 \pm 1,26$ & 13 & $8,00 \pm 0,88$ & 13 \\
\hline $1: 1(\mathrm{M}: \mathrm{C}) 0,5 \%$ & $1,67 \pm 2,08$ & 8 & $4,33 \pm 4,04$ & 3 & $6,33 \pm 5,69$ & 2 \\
\hline $1: 1(\mathrm{M}: \mathrm{C}) 1 \%$ & - & 0 & - & 0 & - & 0 \\
\hline $1: 2(\mathrm{M}:$ C) $0,1 \%$ & $1,43 \pm 0,40$ & 27 & $4,08 \pm 0,65$ & 27 & $6,88 \pm 0,78$ & 25 \\
\hline $1: 2(\mathrm{M}: \mathrm{C}) 0,25 \%$ & $1,40 \pm 0,17$ & 22 & $4,15 \pm 0,17$ & 19 & $7,27 \pm 0,20$ & 15 \\
\hline $1: 2(\mathrm{M}: \mathrm{C}) 0,5 \%$ & $1.78 \pm 0.69$ & 10 & $3,13 \pm 2,80$ & 6 & $5,67 \pm 4,93$ & 6 \\
\hline $1: 2(\mathrm{M}: \mathrm{C}) 1 \%$ & - & 0 & - & 0 & - & 0 \\
\hline $2: 1(\mathrm{M}: \mathrm{C}) 0,1 \%$ & $2,14 \pm 0,47$ & 23 & $4,87 \pm 0,56$ & 22 & $7,70 \pm 0,55$ & 21 \\
\hline $2: 1(\mathrm{M}: \mathrm{C}) 0,25 \%$ & $2,14 \pm 1,87$ & 12 & $3,93 \pm 3,41$ & 11 & $6,07 \pm 5,25$ & 11 \\
\hline $2: 1(\mathrm{M}: \mathrm{C}) 0,5 \%$ & $1,33 \pm 0,58$ & 5 & $4,33 \pm 0.58$ & 3 & $8,67 \pm 0,58$ & 3 \\
\hline $2: 1(\mathrm{M}: \mathrm{C}) 1 \%$ & - & 0 & - & 0 & - & 0 \\
\hline
\end{tabular}

Keterangan: $\bar{x}$ : Rata-rata lama waktu perkembangan (hari)

$\mathrm{n}$ : Jumlah larva yang bertahan hidup

SB : Simpangan Baku

- $\quad$ : Tidak ada larva yang mencapai instar III, IV atau pupa

\section{Konsumsi Pakan Larva C. pavonana}

Berdasarkan hasil percobaan, rata-rata konsumsi pakan pada perlakuan kontrol mencapai $50,30 \%$, sedangkan rata-rata konsumsi pakan yang paling rendah terdapat pada perlakuan 2:1 (Mimba : Cengkeh) $1 \%$ yang menghasilkan rata-rata konsumsi pakan sebesar 2,41\% (Tabel 3). Hal tersebut membuktikan bahwa perlakuan campuran minyak mimba dan cengkeh dengan rasio 2:1 lebih efektif dibandingkan perlakuan tunggalnya dalam menghambat konsumsi pakan seranngga.

Secara tunggal minyak mimba memiliki senyawa antifeedant yaitu azadirakhtin dan salanin yang dapat mengakibatkan penurunan nafsu makan sehingga daya rusak serangga menurun. Minyak mimba juga memiliki senyawa meliantriol sebagai zat repellent, akibatnya serangga enggan mendekati daun berperlakuan (Indiati \& Marwoto, 2008). Sama halnya dengan mimba, minyak cengkeh juga memiliki senyawa flavonoid yang bersifat menghambat makan serangga (Chintihia, 2015).

\section{Bobot Larva dan Pupa C. pavonana}

Berdasarkan hasil percobaan, perlakuan mimba $0,5 \%$ menghasilkan bobot larva instar IV yang paling rendah yaitu sebesar 0,0085 g. Bobot pada perlakuan tersebut lebih rendah dibandingkan perlakuan kontrol yang menghasilkan rata-rata bobot larva instar IV sebesar 0,0307 g. Sama halnya dengan bobot larva, bobot pupa yang paling rendah terdapat pada perlakuan mimba tunggal $0,5 \%$ yaitu $0,0152 \mathrm{~g}$, sedangkan perlakuan kontrol menghasilkan rata-rata bobot pupa yang lebih tinggi yaitu 0,0521 g (Tabel 4). Hal tersebut sejalan dengan hasil penelitian Dono et al. (2020) yang menunjukkan bahwa perlakuan mimba $0,1 \%$ menghasilkan bobot pupa $S$. frugiperda yang paling rendah yaitu $0,1829 \mathrm{~g}$.

Bobot larva dan pupa $C$. pavonana dipengaruhi oleh aktifitas makan larva tersebut. Minyak mimba memiliki senyawa aktif azadirakhtin dan salanin yang dapat berfungsi sebagai antifeedant. Larva yang terpapar senyawa antifeedant tersebut 
menyebabkan aktifitas makannya menurun, sehingga larva akan kekurangan nutrisi yang diperlukan dalam proses pertumbuhan larva akibatnya pertumbuhan akan terhambat dan bobot tubuhnya menjadi lebih rendah (Ramadhan et al., 2016).

Tabel 3. Pengaruh minyak nabati terhadap konsumsi pakan larva $C$. pavonana pada 2 HSP

\begin{tabular}{|c|c|}
\hline Perlakuan & Konsumsi Pakan $\left({ }^{x} \pm \mathrm{SB}\right)(\%)$ \\
\hline Kontrol & $50,30 \pm 6,10 a$ \\
\hline Mimba tunggal $0,1 \%$ & $16,05 \pm 10,89 \mathrm{c}$ \\
\hline Mimba tunggal $0,25 \%$ & $15,11 \pm 13,30 \mathrm{c}$ \\
\hline Mimba tunggal $0,5 \%$ & $11,56 \pm 7,51 \mathrm{c}$ \\
\hline Mimba tunggal $1 \%$ & $4,45 \pm 3,93 \mathrm{c}$ \\
\hline Cengkeh tunggal $0,1 \%$ & $42,02 \pm 4,00 \mathrm{a}$ \\
\hline Cengkeh tunggal $0,25 \%$ & $44,24 \pm 10,79 a$ \\
\hline Cengkeh tunggal $0,5 \%$ & $34,04 \pm 11,86 b$ \\
\hline Cengkeh tunggal $1 \% *$ & $18,94 \pm 6,53 \mathrm{c}$ \\
\hline 1:1 (Mimba : Cengkeh) $0,1 \%$ & $40,27 \pm 8,46 \mathrm{a}$ \\
\hline 1:1 (Mimba : Cengkeh) $0,25 \%$ & $27,87 \pm 9,21 b$ \\
\hline 1:1 (Mimba : Cengkeh) 0,5\% & $17,25 \pm 0,69 \mathrm{c}$ \\
\hline 1:1 (Mimba : Cengkeh) $1 \%$ & $14,77 \pm 3,19 \mathrm{c}$ \\
\hline 1:2 (Mimba : Cengkeh) $0,1 \%$ & $52,89 \pm 9,82 \mathrm{a}$ \\
\hline 1:2 (Mimba : Cengkeh) 0,25\% & $30,39 \pm 19,24 b$ \\
\hline 1:2 (Mimba : Cengkeh) 0,5\% & $19,73 \pm 7,91 \mathrm{c}$ \\
\hline 1:2 (Mimba : Cengkeh) $1 \%$ & $18,58 \pm 8,22 \mathrm{c}$ \\
\hline 2:1 (Mimba : Cengkeh) 0,1\% & $33,12 \pm 17,44 b$ \\
\hline 2:1 (Mimba : Cengkeh) $0,25 \%$ & $21,59 \pm 2,16 \mathrm{c}$ \\
\hline 2:1 (Mimba : Cengkeh) 0,5\% & $13,97 \pm 2,26 \mathrm{c}$ \\
\hline 2:1 (Mimba : Cengkeh) $1 \%$ & $2,41 \pm 2,30 \mathrm{c}$ \\
\hline
\end{tabular}

Keterangan: Angka pada kolom yang sama yang diikuti dengan huruf yang sama tidak berbeda nyata menurut uji Scott-Knott pada taraf nyata 5\%

$\bar{x} \quad$ : Rata-rata konsumsi pakan $(\%)$

SB : Simpangan Baku

* : Data konsumsi pakan diambil pada 1 HSP

Tabel 4. Pengaruh minyak nabati terhadap bobot larva dan pupa $C$. pavonana

\begin{tabular}{lllll}
\hline Perlakuan & Bobot Larva $(\bar{x} \pm \mathrm{SB})(\mathrm{g})$ & $\mathrm{n}$ & Bobot Pupa $(\bar{x} \pm \mathrm{SB})(\mathrm{g})$ & $\mathrm{n}$ \\
\hline Kontrol & $0,0307 \pm 0,0035$ & 28 & $0,0521 \pm 0,0032$ & 26 \\
Mimba tunggal 0,1\% & $0,0154 \pm 0,0133$ & 9 & $0,0308 \pm 0,0270$ & 9 \\
Mimba tunggal 0,25\% & $0,0184 \pm 0,0159$ & 6 & $0,0332 \pm 0,0287$ & 6 \\
Mimba tunggal 0,5\% & $0,0085 \pm 0,0147$ & 6 & $0,0152 \pm 0,0264$ & 6 \\
Mimba tunggal 1\% & - & 0 & - & 0 \\
Cengkeh tunggal 0,1\% & $0,0292 \pm 0,0035$ & 23 & $0,0494 \pm 0,0051$ & 20 \\
Cengkeh tunggal 0,25\% & $0,0281 \pm 0,0040$ & 20 & $0,0494 \pm 0,0060$ & 19 \\
Cengkeh tunggal 0,5\% & $0,0096 \pm 0,0166$ & 7 & $0,0158 \pm 0,0273$ & 7 \\
Cengkeh tunggal 1\% & - & 0 & - & 0 \\
$1: 1$ (Mimba : Cengkeh) 0,1\% & $0,0275 \pm 0,0050$ & 24 & $0,0504 \pm 0,0033$ & 24 \\
$1: 1$ (Mimba : Cengkeh) 0,25\% & $0,0307 \pm 0,0024$ & 13 & $0,0550 \pm 0,0012$ & 13 \\
1:1 (Mimba : Cengkeh) 0,5\% & $0,0222 \pm 0,0228$ & 3 & $0,0158 \pm 0,0296$ & 2 \\
1:1 (Mimba : Cengkeh) 1\% & - & 0 & - & 0 \\
$1: 2$ (Mimba : Cengkeh) 0,1\% & $0,0268 \pm 0,0026$ & 27 & $0,0478 \pm 0,0002$ & 25 \\
1:2 (Mimba : Cengkeh) 0,25\% & $0,0238 \pm 0,0068$ & 19 & $0,0453 \pm 0,0070$ & 15 \\
$1: 2$ (Mimba : Cengkeh) 0,5\% & $0,0159 \pm 0,0150$ & 6 & $0,0308 \pm 0,0268$ & 6 \\
$1: 2$ (Mimba : Cengkeh) 1\% & - & 0 & - & 0 \\
2:1 (Mimba : Cengkeh) 0,1\% & $0,0274 \pm 0,0036$ & 22 & $0,0499 \pm 0,0030$ & 21 \\
2:1 (Mimba : Cengkeh) 0,25\% & $0,0183 \pm 0,0159$ & 11 & $0,0380 \pm 0,0329$ & 11 \\
2:1 (Mimba : Cengkeh) 0,5\% & $0,0234 \pm 0,0008$ & 3 & $0,0497 \pm 0,0075$ & 3 \\
2:1 (Mimba : Cengkeh) 1\% & - & 0 & - & 0 \\
\hline Ketergan: $:$ Rata-rata bobot & & & \\
\hline
\end{tabular}

Keterangan: $\bar{x}$ : Rata-rata bobot larva dan pupa (g)

$\mathrm{n}$ : Jumlah larva instar IV dan pupa yang terbentuk

SB : Simpangan Baku

- $\quad$ : Tidak ada larva yang mencapai instar IV atau pupa 
Keberhasilan Larva $C$. pavonana Menjadi Pupa dan Imago

Perlakuan minyak mimba dan cengkeh secara tunggal maupun campuran menghasilkan jumlah pupa dan imago yang lebih rendah dibandingkan perlakuan kontrol. Perlakuan 1:1 (Mimba : Cengkeh) 0,5\% menghasilkan rata-rata jumlah pupa yang paling rendah yaitu $6,67 \%$, sedangkan pada perlakuan kontrol sebesar 86,67\%. Selain itu perlakuan 1:1 (Mimba : Cengkeh) 0,5\% dan 2:1 (Mimba : Cengkeh) 0,5\% menghasilkan nilai ratarata jumlah imago yang paling rendah yaitu 3,33\%, sedangkan pada perlakuan kontrol menghasilkan ratarata jumlah imago sebesar 60,00\% (Tabel 5).

Tabel 5. Pengaruh minyak nabati terhadap jumlah pupa dan imago terbentuk

\begin{tabular}{|c|c|c|c|c|}
\hline Perlakuan & Pupasi $(x \pm \mathrm{SB})(\%)$ & $\mathrm{n}$ & $\begin{array}{l}\text { Imago yang terbentuk } \overline{(x} \\
\pm \mathrm{SB})(\%)\end{array}$ & $\mathrm{n}$ \\
\hline Kontrol & $86,67 \pm 15,28$ & 26 & $60,00 \pm 10,00$ & 18 \\
\hline Mimba tunggal $0,1 \%$ & $30,00 \pm 30,00$ & 9 & $16,67 \pm 15,28$ & 5 \\
\hline Mimba tunggal $0,25 \%$ & $20,00 \pm 17,32$ & 6 & $13,33 \pm 15,28$ & 4 \\
\hline Mimba tunggal $0,5 \%$ & $20,00 \pm 34,64$ & 6 & $20,00 \pm 34,64$ & 6 \\
\hline Mimba tunggal $1 \%$ & - & 0 & - & 0 \\
\hline Cengkeh tunggal $0,1 \%$ & $66,67 \pm 20,82$ & 20 & $6,67 \pm 11,55$ & 2 \\
\hline Cengkeh tunggal $0,25 \%$ & $63,33 \pm 25,17$ & 19 & $33,33 \pm 23,09$ & 10 \\
\hline Cengkeh tunggal $0,5 \%$ & $23,33 \pm 40,42$ & 7 & - & 0 \\
\hline Cengkeh tunggal $1 \%$ & - & 0 & - & 0 \\
\hline $1: 1$ (Mimba : Cengkeh) $0,1 \%$ & $80,00 \pm 26,46$ & 24 & $36,67 \pm 15,28$ & 11 \\
\hline 1:1 (Mimba : Cengkeh) $0,25 \%$ & $43,33 \pm 23,09$ & 13 & $36,67 \pm 28,87$ & 11 \\
\hline 1:1 (Mimba : Cengkeh) $0,5 \%$ & $6,67 \pm 5,77$ & 2 & $3,33 \pm 5,77$ & 1 \\
\hline 1:1 (Mimba : Cengkeh) $1 \%$ & - & 0 & - & 0 \\
\hline $1: 2$ (Mimba : Cengkeh) $0,1 \%$ & $83,33 \pm 5,77$ & 25 & $36,67 \pm 15,28$ & 11 \\
\hline 1:2 (Mimba : Cengkeh) $0,25 \%$ & $50,00 \pm 26,46$ & 15 & $30,00 \pm 26,46$ & 9 \\
\hline $1: 2$ (Mimba : Cengkeh) $0,5 \%$ & $20,00 \pm 26,46$ & 6 & $13,33 \pm 15,28$ & 4 \\
\hline 1:2 (Mimba : Cengkeh) $1 \%$ & - & 0 & - & 0 \\
\hline 2:1 (Mimba : Cengkeh) $0,1 \%$ & $70,00 \pm 17,32$ & 21 & $33,33 \pm 5,77$ & 10 \\
\hline 2:1 (Mimba : Cengkeh) $0,25 \%$ & $36,67 \pm 32,15$ & 11 & $16,67 \pm 15,28$ & 5 \\
\hline 2:1 (Mimba : Cengkeh) 0,5\% & $10,00 \pm 0,00$ & 3 & $3,33 \pm 5,77$ & 1 \\
\hline 2:1 (Mimba : Cengkeh) $1 \%$ & - & 0 & - & 0 \\
\hline
\end{tabular}

Keterangan: $\bar{x} \quad$ : Rata-rata jumlah pupa dan imago (\%)

n : Jumlah pupa dan imago yang terbentuk

SB : Simpangan Baku

- $\quad$ : Tidak ada larva yang menjadi pupa atau imago

Pada tahap pembentukan pupa ditemukan larva yang gagal membentuk pupa. Pada perlakuan 2:1 (Mimba : Cengkeh) 0,1\%, meskipun larva tersebut sudah diselimuti tanah di sekitar tubuhnya, pupa tetap gagal terbentuk dan larva tersebut kemudian mati di dalam tanah. Pada perlakuan cengkeh tunggal 0,25\% pupa yang telah terbentuk memiliki bentuk yang abnormal ditandai dengan warna kuning kehijauan dan ukuran yang kecil, sedangkan pupa yang sempurna memiliki warna kecoklatan dan ukuran yang lebih besar (Gambar 2). Pupa yang telah terbentuk tidak semuanya dapat berkembang menjadi imago. Pupa yang gagal menjadi imago ditandai dengan warna pupa yang berubah menjadi kehitaman. Sementara itu imago yang muncul pada beberapa perlakuan memiliki bentuk abnormal. Imago abnormal ditandai dengan sayap yang keriting, bahkan pada perlakuan cengkeh $0,25 \%$ imago memiliki kulit pupa yang masih menempel pada bagian tubuh imago (Gambar 3). Imago abnormal tersebut tidak dapat terbang dengan sempurna sehingga kegiatan reproduksinya dapat terganggu.

Azadirakhtin dapat menyebabkan terganggunya sistem hormon serangga seperti hormon juvenile dan hormon ekdison, terganggunya hormon tersebut dapat menyebabkan sterilitas dan kecacatan dalam pergantian kulit sehingga pupa dan imago yang terbentuk memiliki bentuk fisik yang abnormal (Chaudhary et al., 2017). Minyak cengkeh juga dilaporkan dapat menyebabkan penyimpangan morfologi. Menurut Soonwera \& Phasomkusolsil (2016), minyak cengkeh dapat menyebabkan kecacatan pada larva dan pupa, eklosi yang tidak lengkap, serta kematian pada pupa yang normal pada nyamuk Aedes aegypti. 


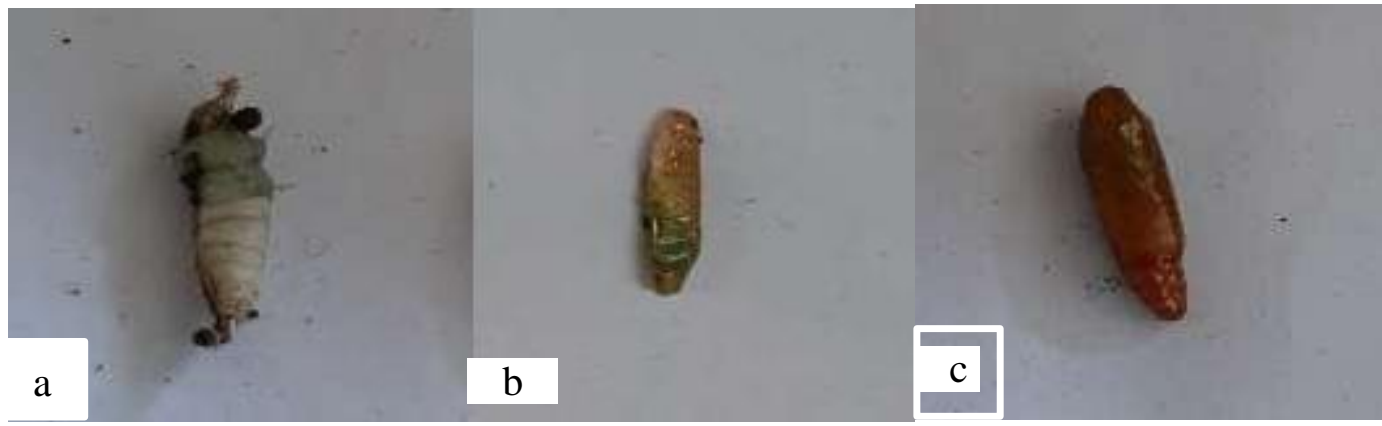

Gambar 2. Pengaruh perlakuan minyak nabati terhadap pembentukan pupa C. pavonana. (a) Pupa yang gagal terbentuk perlakuan campuran 2:1 0,1\%, (b) Pupa abnormal perlakuan cengkeh 0,25\%, (c) Pupa normal perlakuan kontrol.



Gambar 3. Pengaruh minyak nabati terhadap bentuk fisik imago C. pavonana. (a) Sayap keriting perlakuan mimba, (b) Tubuh imago menempel pada kulit pupa perlakuan cengkeh, (c) Sayap keriting perlakuan 1:1, (d) Sayap keriting perlakuan 1:2, (e) Sayap keriting perlakuan 2:1, (f) Imago normal perlakuan kontrol.

\section{Reproduksi Imago C. pavonana}

Imago yang muncul dipisahkan sebanyak satu pasang setiap wadah. Pada percobaan ini, jumlah imago jantan lebih banyak dibandingkan imago betina, sehingga jumlah pasangan imago untuk pengamatan jumlah telur disesuaikan dengan jumlah imago betina yang tersedia. Berdasarkan hasil percobaan perlakuan minyak mimba dan cengkeh secara tunggal maupun campuran dapat menurunkan jumlah telur yang diproduksi imago. Perlakuan cengkeh tunggal $0,1 \%$ menghasilkan jumlah telur yang paling rendah yaitu 29 butir, sedangkan perlakuan kontrol menghasilkan jumlah telur yang lebih tinggi yaitu 387,8 butir. Perlakuan 2:1 (Mimba : Cengkeh) $0,25 \%$ menghasilkan jumlah telur 93 butir, lebih rendah dibandingkan perlakuan mimba tunggal $0,5 \%$ yang menghasilkan telur 134,5 butir (Tabel 6). Hal tersebut membuktikan bahwa perlakuan campuran 2:1 lebih efektif dalam menurunkan produksi telur dibandingkan perlakuan mimba secara tunggal. Minyak cengkeh mengandung senyawa tannin yang berperan sebagai racun perut dengan cara menghambat aktifitas enzim pencernaan, akibatnya serangga yang terpapar minyak cengkeh menjadi kekurangan nutrisi. Kekurangan nutrisi pada tahap larva tersebut dapat berpengaruh pada berkurangnya jumlah telur dan viabilitas telur serangga uji (Milano et al., 2010). Azadirakhtin dalam minyak mimba juga dapat menimbulkan gangguan perkembangan dan reproduksi yang secara langsung dapat berpengaruh pada sel somatik dan jaringan reproduksi serta secara tidak langsung dapat mengganggu proses neuroendocrine (Dewi et al., 2017).

\section{Reproduksi Imago C. pavonana}

Imago yang muncul dipisahkan sebanyak satu pasang setiap wadah. Pada percobaan ini, jumlah imago jantan lebih banyak dibandingkan imago 
betina, sehingga jumlah pasangan imago untuk pengamatan jumlah telur disesuaikan dengan jumlah imago betina yang tersedia. Berdasarkan hasil percobaan perlakuan minyak mimba dan cengkeh secara tunggal maupun campuran dapat menurunkan jumlah telur yang diproduksi imago. Perlakuan cengkeh tunggal $0,1 \%$ menghasilkan jumlah telur yang paling rendah yaitu 29 butir, sedangkan perlakuan kontrol menghasilkan jumlah telur yang lebih tinggi yaitu 387,8 butir. Perlakuan 2:1 (Mimba : Cengkeh) 0,25\% menghasilkan jumlah telur 93 butir, lebih rendah dibandingkan perlakuan mimba tunggal 0,5\% yang menghasilkan telur 134,5 butir (Tabel 6).

Hal tersebut membuktikan bahwa perlakuan campuran 2:1 lebih efektif dalam menurunkan produksi telur dibandingkan perlakuan mimba secara tunggal. Minyak cengkeh mengandung senyawa tannin yang berperan sebagai racun perut dengan cara menghambat aktifitas enzim pencernaan, akibatnya serangga yang terpapar minyak cengkeh menjadi kekurangan nutrisi. Kekurangan nutrisi pada tahap larva tersebut dapat berpengaruh pada berkurangnya jumlah telur dan viabilitas telur serangga uji (Milano et al., 2010). Azadirakhtin dalam minyak mimba juga dapat menimbulkan gangguan perkembangan dan reproduksi yang secara langsung dapat berpengaruh pada sel somatik dan jaringan reproduksi serta secara tidak langsung dapat mengganggu proses neuroendocrine (Dewi et al., 2017).

Tabel 6. Pengaruh minyak nabati terhadap jumlah telur imago $C$. pavonana

\begin{tabular}{|c|c|c|c|}
\hline Perlakuan & Jumlah telur & $\mathrm{n}$ & Jumlah telur $(\bar{x} \pm \mathrm{SB})$ \\
\hline Kontrol & 1551,0 & 4 & $387,8 \pm 138,91$ \\
\hline Mimba tunggal $0,1 \%$ & 288,0 & 1 & $144,0 \pm 50,91$ \\
\hline Mimba tunggal $0,25 \%$ & - & - & - \\
\hline Mimba tunggal 0,5\% & 329,0 & 2 & $134,5 \pm 232,64$ \\
\hline Mimba tunggal $1 \%$ & - & - & - \\
\hline Cengkeh tunggal $0,1 \%$ & 29,0 & 1 & 29,0 \\
\hline Cengkeh tunggal $0,25 \%$ & 286,0 & 1 & 286,0 \\
\hline Cengkeh tunggal $0,5 \%$ & - & - & - \\
\hline Cengkeh tunggal $1 \%$ & - & - & - \\
\hline $1: 1$ (Mimba : Cengkeh) $0,1 \%$ & 794,0 & 4 & $199,3 \pm 164,15$ \\
\hline 1:1 (Mimba : Cengkeh) 0,25\% & 634,0 & 5 & $126,8 \pm 158,97$ \\
\hline 1:1 (Mimba : Cengkeh) 0,5\% & - & - & - \\
\hline 1:1 (Mimba : Cengkeh) $1 \%$ & - & - & - \\
\hline 1:2 (Mimba : Cengkeh) 0,1\% & 574,0 & 4 & $143,5 \pm 98,05$ \\
\hline 1:2 (Mimba : Cengkeh) 0,25\% & 253,0 & 2 & 126,5 \\
\hline $1: 2$ (Mimba : Cengkeh) $0,5 \%$ & - & - & - \\
\hline 1:2 (Mimba : Cengkeh) $1 \%$ & - & - & - \\
\hline 2:1 (Mimba : Cengkeh) 0,1\% & 287,0 & 3 & $95,7 \pm 108,79$ \\
\hline 2:1 (Mimba : Cengkeh) 0,25\% & 93,0 & 1 & 93,0 \\
\hline 2:1 (Mimba : Cengkeh) 0,5\% & - & - & - \\
\hline 2:1 (Mimba : Cengkeh) $1 \%$ & - & - & - \\
\hline
\end{tabular}

\begin{tabular}{cc}
\hline Keterangan: & $\bar{x}$ : Rata-rata jumlah telur \\
$\mathrm{n}:$ Jumlah pasangan imago \\
$\mathrm{SB}:$ Simpangan Baku \\
$-\quad:$ Tidak ada pasangan imago
\end{tabular}

\section{KESIMPULAN DAN SARAN}

Berdasarkan hasil percobaan menunjukkan bahwa perlakuan tunggal maupun campuran (Mimba : Cengkeh) pada konsentrasi $1 \%$ menyebabkan mortalitas larva 100\%, sedangkan perlakuan campuran (Mimba : Cengkeh) dengan rasio $1: 1 \quad 0,5 \%$ mengakibatkan kematian larva $C$. pavonana dengan nilai mortalitas sebesar 93,33\%. Perlakuan campuran dengan rasio 1:1 tersebut pada konsentrasi $0,5 \%$ dapat menghambat terbentuknya pupa dan imago, dan pada konsentrasi
$0,25 \%$ dapat memperpanjang waktu perkembangan larva instar II-III dan instar II-IV. Selain itu perlakuan campuran dengan rasio $2: 1$ konsentrasi $0,5 \%$ dapat memperpanjang waktu perkembangan larva instar IIpupa dan menghambat munculnya imago, konsentrasi $1 \%$ dapat meurunkan konsumsi pakan, serta konsentrasi $0,25 \%$ dapat menurunkan jumlah telur $C$. pavonana. 


\section{ACKNOWLEDGEMENTS}

Kepada semua yang telah membantu kelancaran penelitian ini disampaikan terima kasih. Penelitian ini merupakan bagian dari penelitian bertema "Pengembangan Formulasi Insektisida Botani: Peningkatan Bioaktivitas Berbasis Kombinasi Campuran Bahan Nabati" dengan peneliti utama Danar Dono.

\section{DAFTAR PUSTAKA}

Abizar M. \& Prijono D. 2010. Insecticidal activity of leaf and seed extracts of Tephrosla vogelii $\mathrm{J}$. D. Hooker (Leguminosae) and fruit extract of Piper cubeba L. (Piperaceae) on the cabbage head caterpillar, Crocidolomia pavonana (L.) (Lepidoptera: Crambidae) [in Indonesian]. JHPT Trop. 10:1-12.

Balfas R. 2008. Potensi minyak daun cengkeh sebagai pengendali Planococcus minor (mask.) (Pseudococcidae; Homoptera) pada tanaman lada. Jurnal Bul. Littro. 19 (1): 78-8.

Balfas R, \& Mardiningsih TL. 2017. Pengaruh minyak atsiri terhadap mortalitas dan penghambatan peneluran Crocidolomia pavonana F. Jurnal Bul. Littro 27 (1): 85-92.

Bhat SK, \& Kempraj V. 2009. Biocidal potential of clove oils against Aedes albopictus - A comparative study. African Journal of Biotechnology. 8 (24): 6933-6937.

Chintihia T. 2015. Efek larvasida ekstrak daun cengkeh (Syzygium aromaticum) terhadap Aedes aegypti. Jurnal Agromed Unila. 2 (4): 510-515.

Chaudhary SR, Kanwar K, Sehgal A, Cahill DM, Barrow CJ, Sehgal R, \& Kanwar JR. 2017. Progress on Azadirachta indica based biopesticides in replacing synthetic toxic pesticides. Review. Frontiers in Plant Science. 8 (610): 1-13.

Dewi AALN, Karta IW, Wati NLC, \& Dewi NMA. 2017. Uji efektivitas larvasida daun mimba (Azadirachta indica) terhadap larva lalat sarcophaga pada daging untuk upakara yadnya di Bali. Jurnal Sains dan Teknologi. 6 (1): 126-135.

Dono D, Hidayat Y, Suganda T, Hidayat S. \& Widayani NS. 2020. The toxicity of neem (Azadirachta indica), citronella (Cymbopogon nardus), castor (Ricinus communis), and clove (Syzygium aromaticum) oil against Spodoptera frugiferda. Cropsaver. 3 (1): 22-30.

Duarte JP, Redaelli L, Jahnke SM, \& Trapp S. 2019. Effect of Azadirachta indica (Sapindales: Meliaceae) oil on Spodoptera frugiperda (Lepidoptera: Noctuidae) larvae and adults. Florida Entomologist. 102 (2): 408-412.
Isenring R. 2010. Pesticides and the loss of biodiversity. How intensive pesticide use affects wildlife population and species diversity. Pesticide Action Network, Europe. 26 pp. Development House 56-64 Leonard Street, London EC2A 4LT.

Indiati SW, \& Marwoto. 2008. Potensi ekstrak biji mimba sebagai insektisida nabati. Buletin Palawija. 15: 9-14.

Milano P, Filho EB, Parra JRP, Oda ML, \& Consoli FL. 2010. Effect of adult feeding on the reproduction and longevity of Noctudae, Crambidae, Torticidae, and Elaschistidae species. Neotrop. Entomol. 39 (2): 80-172.

Nailufar N, \& Prijono D. 2017. Synergistic activity of Piper aduncum fruit and Tephrosia vogelii leaf extracts against the cabbage headcaterpillar, Crocidolomia pavonana. J. ISSAAS. 23(1): 102-110.

Prijono D. 1999. Bahan Pelatihan Pengembangan dan Pemanfaatan Insektisida Alami. Pusat Kajian Pengendalian Hama Terpadu. Bogor: Institut Pertanian Bogor. Halaman 1-91.

Ramadhan RAM, Puspasari LT, Meliansyah R, Maharani R, Hidayat Y, \& Dono D. 2016. Bioaktivitas formulasi minyak biji Azadirachta indica (A. Juss) terhadap Spodoptera litura. Jurnal Agrikultura. 27 (1): 1-8.

Soonwera M, \& Phasomkusolsil S. 2016. Effect of Cymbopogon citarus (lemongrass) and Syzygium aromaticum (clove) oils on the morphology and mortality of Aedes aegypti and Anopheles dirus larvae. Parasitology research. 115, 1691-1703.

Sumartini. 2016. Efikasi campuran minyak cengkeh dan ekstrak biji mimba untuk pengendalian penyakit karat (Phakopsora pachyrhizi) pada kedeleai (Glycine max). Jurnal HPT Tropika. 16 (1): 82-89.

Talahatu DR, \& Papilaya PM. 2015. Pemanfaatan ekstrak daun cengkeh (Syzygium aromaticum) sebagai herbisida alami terhadap pertumbuhan gulma rumput teki. Jurnal Biopendix. 1 (1): 149-159.

Wakeil NE. 2013. Botanical pesticides and their mode of actions. Review article Gesunde Pflanzen. 65 (4): 125-149.

Yuswanti L, \& Prijono D. 2004. Pengaruh campuran ekstrak Aglaia harmsiana Perkins dan Dysoxylum acutangulum Miq. (Meliaceae) terhadap mortalitas dan oviposisi Plutella xylostella (L.) (Lepidoptera: Yponomeutidae). Jurnal Hama dan Penyakit Tumbuhan Tropika. 4 (1): 1-7.

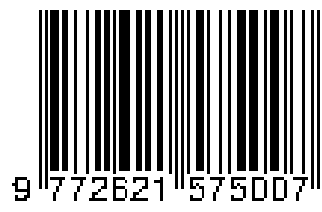

